\title{
The Natural History of the News: An Epigenetic Study
}

John Maxwell Hamilton, Louisiana State University

Heidi J. S. Tworek, University of British Columbia

Published in Journalism: Theory, Criticism, Practice (2016). DOI: 10.1177/1464884915625630

Post-print version of article (i.e. the final manuscript submitted to publisher).

The published version can be found here.

Abstract: Scholars, editors, and reporters have tended to treat news and journalism as synonymous. This conception has privileged a particular kind of journalism often called the Anglo-American model. This study argues journalism has been a type of news reporting for a relatively brief period. Using the concept of epigenetics, the authors argue that journalism is usefully seen as a coating on the DNA of news, which has existed for centuries. Journalism emerged as a result of special factors. As powerful as the Anglo-American model was, it was never fully realized, nor could it become the regnant model throughout the world. Journalism will carry on, but along with many other types of news, all of which carry coatings from the past.

Keywords: Anglo-American journalism, communication history, history of news, journalism, journalism education, journalism history, objectivity, professionalization, Robert Park

Corresponding Author: Heidi J. S. Tworek, University of British Columbia, heidi.tworek@ubc.ca

One reason we know so little about the newspaper is that as it exists today it is a very recent manifestation. Besides, in the course of its relatively brief history, it has gone through a remarkable series of transfigurations. The press today is, however, all that it was and something more. To understand it we must see [it] in its historic perspective.

Robert E. Park

"The Natural History of the Newspaper" 


\section{Introduction}

"He was pretty wild when young, expecially addicted to common Wenches," seventeenth-century chronicler John Aubrey (2000: 47-48) wrote of his contemporary Sir Henry Blount; "I remember twenty years since he inveighed much against sending youths to the Universities, because they learnt there to be debauch.”

This passage and others like it in Aubrey's Brief Lives remain quaintly amusing, but they are more than artifacts of a bygone time. Aubrey is thoroughly modern. Like those who comment on Facebook or post on Instagram an iPhone photo that goes viral, Aubrey was a self-appointed and far-from-fulltime reporter. A financial ne'er-do-well, his interests ranged from mathematics to painting to archaeology, in which he was a pioneer. Like many modern bloggers, he set his own standards. He enjoyed passing along gossip. Of John Barclay, a popular Scottish satirist, Aubrey (2000: 36) observed, "Dr. John Pell tells me, that his last employment was, Library-keeper of the Vatican, and that he was there poysoned." His audience was small; his motivation often self-promotion.

Aubrey is a useful object lesson in two respects. First, he reminds us that news is about more than journalism. News existed before professional reporters and editors, before the ideas of fairness and objectivity, before newspapers. As Robert Park wrote in the 1920s, the newspaper was "a recent manifestation." The newspaper is just one way of reporting news and the end of the printed newspaper does not mean the end of news.

Second, the reemergence of Aubrey-like journalism suggests a revised conception of Park's "Natural History of the Newspaper." Park turned to evolution for a metaphor to describe the newspaper. We have turned to the cutting edge in evolutionary biology to take his argument further. Park (1923: 273) viewed the newspaper as "not wholly a rational product." It had "a natural history" because no group could control or foresee its development. But where Park saw the press as "a history of a surviving 
species," we view news as a history of inherited and mutating practice that incorporates journalism, but does not depend upon it. Unlike Park, who saw "the newspaper," we see many ways of disseminating news in history, from songs to jokes to today's multi-platform media. Journalism and news are different, but intertwined. Both news and journalism have evolved over time. Those evolutions did not always occur simultaneously. Sometimes the changes in news and journalism were related, sometimes not.

So how can we understand the "natural history" of news and journalism, two interconnected, but not synonymous phenomena? The history of journalism, as we see it, is better understood as an epigenetic phenomenon. Epigenetic changes are inherited effects, but they are not picked up in the same way as, say, hair color. At its most basic level, the contemporary field of epigenetics is "the study of heritable changes in gene expression that are not caused by changes in DNA sequence" (Slatkin, 2009: 845). ${ }^{1}$ Essentially, an offspring's DNA is “coated,” as biologists put it, by ancestral experience. Emotional stress experienced by parents, for instance, can leave marks on the chemical coating (methylation) of offspring's chromosomes determining their reactions to stress (Dias and Ressler, 2014; Kellermann, 2013). Or parents can pass down changes in the proteins that package their children's DNA.

In our reading of history, news is DNA. In certain circumstances, journalism has been its packaging. Always people have wanted to know about events around them; always there have been people to tell them. But DNA and its coating mutate over generations. The types of news and the conventions for providing news, the chemical or protein packaging, have been in flux, changing depending on environmental factors and coated by past experience.

The most prominent coating for news is the modern Anglo-American model of journalism. Journalism is a professional discipline of reporting news based on particular Western belief systems that emerged in the late nineteenth and early twentieth centuries (Nerone, 2013). This model placed a high

\footnotetext{
${ }^{1}$ For another study using scientific concepts to explain change over time, in their case the biochemical concept of autocatalysis, see Pagett and Powell, 2012.
} 
value on ethics and professional solidarity. Many historians as well as many journalists regarded these values as universal, permanent standards for news just like Francis Fukuyama's End of History (1992) argued that the end of the Cold War had settled all the big questions about forms of government. History and biology do not work that way. The Anglo-American model of news emerged in a specific time and place for specific contextual reasons - economic, technological, sociological etc. Even then, the values of that model were often honored in the breach. Journalists displayed traits found in Aubrey's time - the sensational, the personal, the venal. This twentieth-century moment of high professionalism is an exception in the history of news, not its defining moment.

Looking at the history of journalism as epigenetic makes for a far more optimistic story. News changes, but survives. Anglo-American journalism was one type of journalism coating the DNA of news. Such a historical perspective also moves beyond a Western-centric analysis of journalism (Zhao, 2012: 144) to focus instead on the practices of news-gathering that can mutate and intermingle over time. Thinking of news and journalism as interrelated, but separate phenomena underscores the transgenerational transmission of methods of information collection. The alternative forms of news arising today carry not only markers from Aubrey's time but also from the Anglo-American model.

\section{The rise of the Anglo-American model: a contested history of place and time}

Five standard explanations exist for why the Anglo-American model of journalism emerged when it did. All are rooted in the last 150 years and many scholars have examined the different factors as well as their interaction (Nerone, 2013). No explanation is entirely satisfying. But of significance for us is that these accounts so often suggest causal factors that also existed elsewhere but did not bring about a similar change in practice. Even within the Anglo-American model, differences existed. Just as children from the same parents can turn out very differently, the DNA of news could have very different coatings. 
The first is the most teleological (and most discredited) explanation - the moral narrative. This sees journalism as a sine qua non for newspapers acting as a Fourth Estate. While the origins of the term "Fourth Estate" are murky, Thomas Macaulay (Splichal, 2002: 44) declared in 1827 that "the gallery in which reporters sit [in British Parliament] has become a fourth estate of the realm.” By 1835, William Hazlitt (1835) described William Cobbett as "a kind of fourth estate in the politics of the country," meaning Great Britain. "Impartially and remorselessly," wrote Hazlitt, Cobbett attacked those on the right and the left. In this telling, journalists became the keepers of the Fourth Estate and a group that told truth to power.

In 1923, Robert Park (1923: 273) dismissed this explanation as overly simplified. "The press, as it exists, is not, as our moralists sometimes seem to assume, the wilful [sic] product of any little group of living men." Nevertheless, the idea (Hudson, 1873: 738-9) has survived in extravagant journalistic claims to moral authority, such as the slogans dating back to "I'll put a girdle around the earth in forty minutes" (Boston Saturday Evening Gazette), and “Tout le monde” (London's New York Diary) and remaining in our modern time: “All the News that Is Fit to Print" (New York Times) or "The World's Greatest Newspaper" (Chicago Tribune).

A second narrative focuses on the economic reasons for creating non-partisan newspapers. Starting in the mid-1840s, news became a mass market product. News print was made from cheap wood pulp rather than more expensive rags. Steam-powered rotary presses enabled printing on a large scale. At the same time, industrialization and burgeoning urban centers created a large audience that advertisers wanted to reach. To attract the largest number of readers possible, the news media became less tied to political parties and more independent. This led to journalistic conventions that emphasized a neutral attitude toward news (Hamilton, 2004: ch. 2). 
This argument is rooted in an American context, but also describes how the growth of the mass press redefined journalism elsewhere (Steel and Broersma, 2015). In Germany, the newspaper genre of the Generalanzeiger (general advertiser) emerged in the 1880 s as a cheap, non-partisan paper subsidized by advertising. These newspapers sprang up in rapidly urbanizing areas and targeted the new city-dwellers for their pennies, not to change their politics.

Yet, the presence of advertising did not always create non-partisan papers. Under the Soviet Union's New Economic Plan of the 1920s (Kenez, 1985: 225-31), newspapers had to balance their books. Newspapers had initially received free paper and distribution subsidies after the 1917 October Revolution. Advertisements and commercial notices were forbidden. By the early 1920s, however, newspapers were permitted to use advertising to subsidize their product. In 1922 and 1923, adverts comprised one-eighth to one-quarter of the space in Soviet newspapers. Along with Soviet rules that every Party member had to read a Party publication, thus boosting subscriptions, advertisements enabled Soviet papers to increase circulation from 1.5 million in January 1923 to over 7 million by January 1925. But those advertisements did not foster a non-partisan press. Newspapers printed Soviet-flavored news and barely reported on significant domestic news or human-interest stories.

A third narrative places the rise of journalism in the context of late nineteenth- and early twentiethcentury professionalization in areas like business, engineering, or medicine. At the same time as lawyers sought to codify common law, reporters developed guidelines for practices such as interviewing and factbased reporting (Schudson, 1990). Like engineers (Malatesta, 2011: ch. 3), journalists created professional societies to solidify their status. But these developments did not occur simultaneously or even identically in Britain and America - or for that matter elsewhere. Early in the twentieth century, for instance, when American journalists almost fetishized interviews, the British sniffed at them. 
These differences are also clear in the varied emergence of journalism associations and education. The American Society of Professional Journalists was founded in 1909, followed by the American Society of Newspaper Editors (ASNE) in 1922. The first successful journalism school was founded in 1908 at the University of Missouri. That same year, Harvard Business School was created in a similar effort to establish professional credentials for management. At journalism schools, journalism textbooks legitimized the norm of objectivity (Maras and Nip, 2015; Vos, 2012).

The British founded professional organizations just as eagerly. The National Association of Journalists, created in Birmingham, England in 1884, received a Royal Charter to become the Charter Institute of Journalists in 1890. A competing National Union of Journalists emerged in 1907. Those journalists, however, saw themselves more as tradesmen who needed a trade union and who practiced a craft. As for journalism education, W. T. Stead (1891) declared that "the only school of journalism" was writing in print for free "until you can find someone to pay you for your copy." That reluctance to provide serious collegiate education for British journalists persisted until the late twentieth century.

But countries with different forms of reporting from Britain and the United States also had professional associations. Although continental Europeans were skeptical that journalists were professionals like lawyers or doctors, Germans founded associations around the same time as Americans and Brits, like the Association of German Newspaper Publishers (Verein Deutscher Zeitungsverleger) in 1894 and the Federal Association of the German Press (Reichsverband der Deutschen Presse) in 1910. The University of Leipzig created the country's first Institute for Newspaper Education (Institut für Zeitungskunde) in 1916, just eight years after the University of Missouri had founded the first American school of journalism. If the hallmarks of professionalization were schools and associations, continental Europeans had them too, though their reporting read differently from the Anglo-American world. 
A fourth narrative holds that conventions like the inverted pyramid facilitated the emergence of journalism. As telegraphic messages were expensive and sometimes unreliable, the inverted pyramid allowed journalists to send the most important information first. Editors could easily abridge articles to fit the space available. This led to stripped-down, fact-based reporting. Conciseness became a defining characteristic of Anglo-American journalism.

While these ideas about journalistic style took root in America, they did not elsewhere. The telegraph entered into the DNA of news, but it did not create the same inverted pyramid coating everywhere. Louis Lochner, the Associated Press correspondent in Berlin from 1924 to 1941, sought to persuade German journalists that the inverted pyramid was a useful technical method to retain the most important elements of a story, even if the commissioning editor snipped off most of the rest of the article to save space. Germany was itself advanced in the use of communications technology. It had the tallest wireless tower in the world in 1917. But Lochner's idea did not appeal to his German interlocutors. They considered the writing of newspaper articles as a subjective, intellectual endeavor rather than a technical service. Based on this experience, Lochner (1931: 3) believed the inverted pyramid's success arose "from the mentality of the American who wants to know the essence of a matter in a lean, concentrated form and then decides whether to continue reading depending upon his time and interests."

Finally, a fifth narrative privileges political systems. This is often broadly based on the Habermasian idea of an Enlightenment public sphere or the constitutive frameworks of liberal democracies, particularly the United States (Starr, 2004). One reading views the standard of objectivity as rooted, ironically, in partisan politics and particularly the American Civil War. On this reading (Mindich, 1998: ch. 3), Edwin M. Stanton, Lincoln's Secretary of War, first used the inverted pyramid to control information and mold it to the North's advantage. The word "objectivity" itself, however, only became common currency in journalism in the 1920s (Knowlton and Freeman, 2005; Schudson, 2001). Also 
ironically, the term emerged from discussions about how to salvage journalism and newspapers from their reputation as partisan purveyors of Wilson's war. Bylines, for instance, became more frequent in the 1920s to show the origins of a news item and to establish greater credibility. For Walter Lippmann (1931: 4401), journalism could not be a profession "until modern objective journalism was successfully created and with it the need of men who consider themselves devoted, as all the professions ideally are, to the service of truth alone."

Again this history was not repeated elsewhere in quite the same way. While bylines became a standard feature of "objective journalism" in the United States, putting the name of a correspondent under an item actually indicated the very opposite in continental Europe. In the interwar period, correspondents' names often appeared below news items. Even short telegraphic dispatches frequently were signed with initials. For Arthur Koestler (1983: 226), later celebrated for his anti-totalitarian novels like Darkness at Noon, the bylines were there "as if to underline the subjective nature of his [the correspondent's] reports." Koestler worked as a journalist for several German newspapers in the interwar period. He reminisced polemically after the war that objectivity was the main tenet of Anglo-Saxon journalism, while Germans subjectively relayed the politics of the paper. A correspondent would "use facts as pretexts for venting his opinions and passing oracular judgments." European journalists frequently did not see objectivity as a guiding ideal. While partisanship may have fostered objectivity in the United States, the partisan politics of the Weimar Republic did not create a non-partisan press (Fulda, 2009).

These five overlapping arguments about journalism, while often good descriptions of what happened at the time, only describe an era of journalism, and not necessarily one that must be Whiggishly progressive - that is to say, one that must continue evolving in the same direction. The hallmarks of the development of journalism and the objectivity norm did not create the same ideals and practices in the US and Great Britain, let alone in the rest of Europe. The chemical coating of chromosomes can cause some 
children to be more resilient to stress and others to be more vulnerable. In journalism, too, similar contextual factors like new technologies or state formation could create very different reactions. Techniques and developments like professional associations or bylines did not contribute to the same rise of objectivity norms in a place like Germany. Advertising served a very different purpose than nonpartisanship in the early Soviet Union. Even in the United States, the actual practice of reporting often differed starkly from the rhetoric of journalists and editors.

\section{Honoring convention in the breach}

The concept of modern journalism possessing an established set of functional standards is convenient for assessing the quality of one kind of newsgathering. But it is ahistorical. If we mark the beginning of modern journalism in the 1840s and the end at, say, 2000, when new technologies brought enormous change, we see that well into the modern era journalists struggled to figure out what good journalism was. When they did generally agree on principles, journalists struggled to meet them. Just as we cannot understand the variety of humanity's genetics and epigenetics by examining a few human beings, we cannot understand journalism by reading only large, elite newspapers, which generally displayed the highest standards within the profession at the time. Here we examine three instances when American practice differed from the idealized Anglo-American model of journalism. We also consider the methodological problems with asserting normative standards for journalism with a limited sample of large, urban newspapers.

The Case for Foreign News. One argument for journalism as "an Anglo-American invention" rests on foreign reporting. British and American journalists were supposedly the first in the field with permanent journalists who gathered fact-based news in large amounts (Chalaby, 1996). Exhibit A in this argument has been James Gordon Bennett's New York Herald beginning in the 1840s. Frederic Hudson, whom 
Bennett hired to collect foreign news from ships arriving in port and later became the Herald's managing editor, wrote one of the earliest histories of American journalism. He (1873: 451) considered Bennett the originator "of organized European correspondence."2

But Bennett's foreign correspondents were not full-time members of his staff. They were parttimers with other jobs. Many, Bennett boasted, were volunteers. The Herald's Jamaica correspondent was a local journalist who wanted to exchange newspapers with Bennett. Early correspondents from Liverpool and Le Havre worked in brokerage firms, which dovetailed with the Herald's emphasis on commercial foreign news. Bennett buttressed this reporting with the well-established convention of running letters from American travelers, who were as assorted in occupation as naval officers and actors.

The newspaper that probably did more than any other to establish the norms of modern journalism was the Chicago Daily News. Around 1900 its owner, Victor Lawson, decided it was time to have a team of American foreign correspondents report for American readers. But just what they should cover was unclear. At first the paper ran a recurring column from London, "Queer Sprigs of Gentility," which Lawson sent to other newspaper owners in hopes of enticing them to subscribe to the foreign news service he wanted to build. Even when the paper excelled at significant reporting abroad, its correspondents fretted Lawson "did not care a hoot about foreign news" (Swing, 1964: 37). The New York Times, which subsequently became the premier American newspaper for foreign news, was heavy with non-American foreign correspondents for years. In the late 1920s, Wythe Williams was the only Times bureau chief in a continental capital to carry a U.S. passport (Hamilton, 2009: 162).

The Daily News, which sold for a record price to each new owner, was shuttered in 1978. The New York Times has maintained a quality foreign service for years. But foreign news has remained a tenuous part of American journalism. The cost of gathering foreign news is high and the level of readership is low.

\footnotetext{
2 This same point is made in Chalaby, 1996: 306-7.
} 
The exception comes when the United States sends its men and women into war, but that increase in coverage is because the news has a strong domestic angle. The share of overseas news throughout the twentieth century always went down when troops came home (Allen and Hamilton, 2010).

The Case for Independence. Another norm for modern journalism is the independence of the news media. This is sometimes expressed in terms of impartiality, objectivity, or the absence of conflicts of interest. But if the term Fourth Estate signifies journalism's separateness in the governing process, it also suggests that it is part of the process. Journalism has been a good route into government, and government a good route back to journalism. One of the best reporters of the time, muckraker Ray Stannard Baker (2012), whose integrity was impeccable, went overseas during World War I ostensibly as a reporter, but in fact worked secretly for the Wilson Administration. Concerned about the quality of reports from its embassy in London, the State Department wanted Baker to provide reports on British attitudes toward the war. During this period he did not write a single report for publication. Not only flamboyant figures such as William Randolph Hearst sought high elected office. To use the respectable Chicago Daily News yet again, one of its owners, Col. Frank Knox, ran for vice-president on Alf Landon's ticket in 1936 while presiding over the paper.

Most modern American journalists would not admit to parallels with Germany of 1912, when 14 percent of SPD (Social Democratic Party) candidates described themselves as journalists (Hall, 1977: 32), or of Germany during the Weimar Republic, when 49 percent of SPD members of parliament had been involved in party journalism at some point during their careers (Schröder, 2009). But the differences between Germany and the United States are only a matter of degree.

None of this means that journalists did not gradually form ethical standards promoting independence. Baker's work for the Wilson administration is considered unacceptable today among establishment news media. But even in the late twentieth century, the line between government and 
journalism was routinely crossed. Also journalists lose independence in subtle ways by adhering to vaunted news conventions. A prime example of this is the phenomenon of indexing, a term political scientists use to describe news media bias toward power. The argument, simply put, is that coverage, in times of national security crises, tends to trace the contours of official views. As one of the more important of these studies (Bennett et al., 2007: 100) puts it, "Once officials engage with news events, the story frames generated by journalists are then generally 'indexed' to the range of sources and viewpoints that reflect levels of official agreement and consensus." When consensus within the government is strong, the range of views in the news media tends to be narrow. When the range of official views widens, coverage tends to widen with it.

Two other factors lead to the pattern of reporting described by indexing. First, elite reporters and columnists have much in common with elite policy makers. They have similar educations and vacation preferences. They are less likely to bond with dissident non-establishment sources. Second, journalists and policy makers have a keen mutual interest in keeping lines of communication open. Reporters are better positioned to pick up news about government plans and action, and policy makers are better able to build public support for their points of view.

The Case for Normative Journalism. Arguments about normative standards in modern journalism frequently extrapolate from a small number of newspapers - most of them elite and not read by the great mass of Americans - to characterize all Anglo-American journalism. Accordingly, our understanding of Anglo-American journalism has been determined as much by our narrow range of evidence as our fixation on idealized journalistic standards.

This approach has been driven by convenience. Before the mass digitization of newspapers through the Library of Congress' Chronicling America database (www.chroniclingamerica.loc.gov) or commercial providers like ProQuest, scholars often had easy access to a small handful of large urban 
newspapers. The practice of using The New York Times as a yardstick for journalism has a long and venerable tradition (e.g. Lippmann and Merz, 1920; Hallin, 1986; Winder and Schmitt, 2014). The ease with which we could study that paper, as well as its status as the newspaper of record, has meant that much of the modern history of journalism has been a history of the New York Times, which most people did not read.

Our point is not that anyone who wrote before the mass digitization of newspapers is wrong as far as the research took them. Rather, we have a chance to understand the broader applicability of those findings. Scientists (Johnson, 2015) increasingly recognize the problem of irreproducibility in experiments. The beauty of history is that we can easily reexamine our materials. It costs millions to rerun a scientific experiment. It costs a few days of time to revisit historical analysis and to rerun our “experiments" with much more data from many digitized newspapers.

The Viral Texts project (www.viraltexts.org) on reprinting culture in the nineteenth century is already doing this kind of work. The project found, for instance, that quotidian, practical articles, or what Ryan Cordell (2015) has called "information literature," were the most widely reprinted. The second most reprinted article in the project's database prior to 1861 was a recipe for gum arabic starch. Newspapers like the Sunbury American from Pennsylvania and the Glasgow Weekly Times from Missouri, which provided such stories, were surprisingly central to American networks of reprinting. Newspaper culture, it seems, was far more diffuse in the antebellum United States than scholars had assumed.

Let's take a look at one of the most prominent studies on the development of journalism conducted prior to mass digitization of newspapers. In 1995, Michael Schudson examined coverage of State of the Union addresses. He drew most from the New York Times, Chicago Tribune, Washington Post, and Washington Evening Star with a few scattered years from ten other urban papers. Schudson argued that 
coverage of the State of the Union addresses incorporated new conventions during the late nineteenth century that became standard journalistic practice in the twentieth.

Journalists, he found, used a summary lead and inverted pyramid over a chronological narrative; they made the president the most significant figure; their stories on important speeches and documents quoted or included the main points; they placed the news story in a longer chronological context than just the event itself. The main point for Schudson (1995: 68) is "that the modern conventions of news reporting emerged at a time when politics was coming to be thought of as administration." These new forms allowed journalists to convey the intentions of political actors and to give stories meaning.

Schudson's argument is persuasive for the newspapers that he examined. But we can now discover whether the findings stand up to wider scrutiny. Consider Schudson's claims regarding the newspapers he examined in 1900. Schudson (1995: 59-60) found that the news story focused on a chronological narration of the reopening of Congress. The president's message was always printed in full on another page, but any mention of the message in the news story on Congress occurred deep into the article. The news story did not refer to the president by name, but called him "the president." Nor were the contents of his message described.

Our search on Chronicling America and ProQuest Historical Newspapers for reporting of the State of the Union address in 1900 confirmed many of Schudson's assertions. Newspapers like the Boston Daily Globe or the Baltimore Sun displayed the same conventions as other large urban papers. But newspapers from rural areas or smaller towns showed more variation. The Forest Republican (December 5, 1900: 1) in Tionesta, Pennsylvania, for instance, printed President McKinley's message on the front page in full with no news story on Congress at all. The Times (December 4, 1900: 1) of Richmond, Virginia, printed the Associated Press' story on the reopening of Congress on its front page. But it published the Associated 
Press' transcription of McKinley's speech in the far left-hand column on the front page too. ${ }^{3}$ The St. Paul Globe of Minnesota (December 4, 1900: 1) gave far greater typographical prominence to McKinley’s speech, placing it over the three far-right columns of the front page and only giving Congress the far-left column.

Even a prominent daily, the Atlanta Constitution (December 4, 1900: 1), took a different approach from the New York Times and other papers in Schudson's sample. It had a bordered box in the middle column of the front page with "points of interest from president's message." Below an illustration of the head pro tempore of the Senate, William P. Frye from Maine, the president's message itself and the president were front and center of coverage. The news story on the opening of Congress focused on Congress in the lead paragraph, but the second paragraph already delved into the contents of the message and, more importantly, what the president omitted (the question of trusts). Subsequent paragraphs mentioned McKinley by name.

A wide dragnet of sources can confirm our established understanding of Anglo-American news. But a broader array of sources can overturn it. Bob Nicholson's research (2012) has demonstrated, for example, that the culture of reprinting could take an American joke in the late nineteenth century from Nevada via New York to British publications, whose readers would retell it in political meetings in North Wales. Where many historians previously only found elite disdain for the United States, Nicholson found enthusiasm. While Dickens quarreled with America in 1842 (Moss, 1984), British provincial newspapers eagerly reprinted and appropriated American jokes, snippets, and sayings. Our previous conceptions of Anglo-American journalism might not just be limited in their conclusions. They may be way off base.

\section{Why the good times couldn't last: the economics of the Anglo-American model}

\footnotetext{
${ }^{3}$ News agencies (Nalbach, 2003; Silberstein-Loeb, 2014; Tworek, 2013), like reprinting, are an important part of the broader rise of Anglo-American journalism, though newspapers could choose how to place stories or whether to print them.
} 
This brings us back to the central argument in this paper, the exceptional nature of the AngloAmerican model of journalism and its place in the epigenetics of journalism. Historians and journalists have idealized those professional standards, implicitly assuming that the conditions that gave rise to them were set once and for all. A good place to reconsider this assumption is with the economics underpinning Anglo-American journalism.

Anglo-American journalism, practiced at a high level, is expensive. Foreign bureaus and investigative reporting are costly as are state and national news bureaus, stand-alone Sunday book reviews, and specialized reporting on health, science, and business. The high point of Anglo-American journalism, when its values solidified into near mythology, was in the last half of the twentieth century when news businesses' coffers brimmed. During that time, Robert Picard (2003: 128) has observed, "print media became one of the most profitable business in the developed world." Newspapers enjoyed average annual returns of 12 percent; magazines were nearly as high at 10 percent. Some newspapers enjoyed profits of 30 percent. During that same time, grocery store profits were in the two percent range and department stores around four percent. At annual meetings of the American Society of Newspaper Editors in the 1990s, when the profit picture began to change, editors routinely turned to a single solution to any problem - owners (or shareholders) should spend more money on news.

The assumption was that the news should not conform to the normal rules of business. Of course it has. American mainstream news thrived during a certain time in history because of a complex set of subsidies (John and Silberstein-Loeb, 2015). Advertisers subsidized American newspapers to reach the mass market of consumers that arose in the late nineteenth century. By the mid-twentieth century, advertisements covered about 80 percent of newspaper operating costs. Readers paid the remaining 20 percent, which roughly equaled the cost of delivery, so advertisers subsidized readers as well. The resulting news product was relatively cheap and thus attractive to the great mass of potential consumers 
(Hamilton and Krimsky, 1996: 24). Readers also subsidized each other. As a mass media product, the newspaper sought to have something for everyone. The reader who cared little about hard news paid for the paper to learn sports scores, television listings, and supermarket sales. Expensive news, such as investigative journalism, was paid for by people who very often didn't read it. ${ }^{4}$

These subsidies were anomalous, however. Newspapers grew more profitable because others failed, allowing the survivors to attract ever-larger audiences. In effect the rich became richer. But then came technological disruption. The first technologies to challenge the printed press were radio and television. This was offset because those media initially provided a limited amount of news and because the number of newspapers continued to decline, reducing print competition. But new entrants to the news field soared with the Internet, which had very low costs to entry for anyone who wanted to provide news. Besides this, news consumers who wanted sports scores could get all they wanted online, all day, for free. Newspaper penetration halved from 1950 to 2000. As Picard has pointed out (2008: 113), declines in newspaper penetration began well before technological disruption, but that phenomenon accelerated the decline. Without a large readership base, advertisers have less interest in subsidizing traditional media. With all sorts of places to get the news and the ads they care about, consumers no longer subsidize other readers with different interests to the degree they once did.

This is not to say the Anglo-American model will not persist. It will. News has changed, becoming more available, more frequent, and more ubiquitous. Reporting the news has changed too. Journalism will inherit the markers of the Anglo-American model. But fewer news organizations will practice it, and those will have to embrace new professional norms to succeed. Ten years ago no New York Times editor would countenance advertising that mimicked news, as it would blur the strong line that separated the editorial

\footnotetext{
${ }^{4}$ Of course, as with every other aspect of the Anglo-American model, there were exceptions - the BBC, supported by taxpayers, and the church-supported Christian Science Monitor. Because they lived in a sea of for-profit news organizations they adopted the dominant news values, differing chiefly in showing more fidelity to them.
} 
functions from the rest of the paper. Today native advertising accounts for ten percent of the Times' digital revenue (Sebastian, 2015). While many of these developments seem earthshattering for those inside traditional newspapers, they are not wholly novel. They draw on the older DNA of news and coatings of reporting, particularly in the early modern era before the dominance of the newspaper.

\section{Conclusion}

Robert Park (1923: 289) concluded his seminal study by noting "that we have not studied the newspaper as the biologists have studied, for example, the potato bug." Unlike biologists' studies on potato bugs, epigenetics is a young field for science too. There is much to learn about the relationship between DNA and its epigenetic coatings. The same applies to the connection between news and journalism. We have a good starting point to think about this history when we consider how the two are historically related to each other.

The Anglo-American model tempts us to ahistorical thinking. In its prime, the model functioned almost miraculously well. Interlocking subsidies paid for broad distribution of expensive-to-gather news that only a few wanted to read but was valuable to the functioning of democracy. An admirable ethic built up around this model for fair, fact-based reporting, even if those goals were elusive in practice. But people have always cared about news. They have just found different modes to gather and consume that news. The newspaper took several centuries to become the most popular mode of disseminating news from its emergence in the early seventeenth century to its dominance in the nineteenth and twentieth centuries (Pettegree, 2014). People gossiped about news, they sang songs, and they spread rumors. In prerevolutionary Paris, they gathered under a tree, the Tree of Cracow, to swap stories about French elites (Darnton, 2000). In Paris, as elsewhere, news was cosmopolitan: cities were hubs of information, just as is the case today (Rantanen, 2007; Sassen, 2001). 
Our news chromosomes have a long history, even as epigenetics coated those chromosomes with different forms of finding and telling the news. Old forms of news seem new to many commentators, when they are often manifestations of long-standing habits that never completely disappeared. The contemporary news environment is increasingly filled with citizen journalists supplying news for free over platforms ranging from Twitter to the Huffington Post. People operate independently, without editorial supervision, like our man Aubrey in the seventeenth century. Individual observations can be packaged and repackaged into news (whether about cats on morning television news or bombs in Syria). These individuals, like the unemployed Eliot Higgins who became the leading expert on munitions in Syria (Keefe, 2013), are unpaid, but their skills and information provide crucial fodder for commercial media companies.

Early modern news was often not so much independently produced as curated from multiple sources. Reprinting was rampant. Among other American government support given journalists, the Post Office subsidized that behavior by providing newspapers with the right to exchange copies for free. (Cook, 2005). In 1832, newspapers comprised 95 percent of the weight of the post in the US, but only provided 15 percent of the revenue (John, 1995: 38). Despite legal attempts to prevent news organizations from lifting news from their competitors, curation never completely died during the nineteenth and twentieth centuries. It happened nonetheless, mainly through news agencies providing global and national news to a large number of newspaper customers. Today, we as news consumers are constantly confronted with curated content, much like New England and European newspaper consumers 300 years ago.

As a Briton and an American, we recognize the Anglo-American model's virtues and believe it will continue. But it will not continue in as uncontested a fashion as in Great Britain and the United States during the twentieth century. It will coexist with other models that will flourish. Epigenetic factors, especially new technologies that have disrupted the Anglo-American model, have paradoxically retrieved 
older coatings of the DNA of news. In our "news" today we can see the tattler, the party pamphlet, the recondite journal of opinion, the yellow rag, the journal of commerce, the sob sister, the literary journal, and the progressive muckraker. The blog, an updated Tree of Cracow (Darnton, 2013), and the amateur citizen journalist, toiling solitarily as Aubrey did, exist side-by-side with the school-trained reporter in a large newsroom.

This is not a break in the historical narrative of news. It is a continuation of it. First, AngloAmerican journalism has always been one coating on the DNA of news. Alternative coatings have thrived elsewhere because of the environments in which news was gathered and conveyed. Germans had professional press associations, for instance, but had long thought of reporting as a subjective endeavor. There was never much hope for the Anglo-American model in countries where the public had low literacy and oligarchs controlled the press. The model could neither thrive nor serve the public as well as other approaches until socio-political structures changed. But news spread through other channels. Jokes, for instance, conveyed vital information in East Germany, which is why the West German Secret Service monitored them. (Hertle and Saure, 2015).

Second, as Park noted, newspapers are a relatively recent invention and the Anglo-American model newer still. American journalism is younger than American baseball. To expect this model to become a permanent model, whatever its virtues, is the equivalent of Athenians in $400 \mathrm{BC}$ thinking that their quasi-democracy would not only last forever but also be widely emulated by others.

Just like our genetic and epigenetic mutations, both news and journalism are constantly evolving. Journalism is one chemical coating on the chromosomes of news. We do not venture to say exactly how journalism will evolve in the future. We are only confident that journalism, in whatever form, will not become extinct. We will not go back so far in history as the Dublin Gazette, which in November 1670 ceased publishing because "there was no news" (Fraser, 1979: 315). 


\section{$\underline{\text { Bibliography }}$}

n.a., Forest Republican (December 5, 1900), p. 1. Available at: http://chroniclingamerica.loc.gov/lccn/sn84026497/1900-12-05/ed-1/seq-2/ (accessed 30 May 2015).

n.a., The Atlanta Constitution (December 4, 1900), p. 1. Accessed through ProQuest (30 May 2015).

n.a., The St. Paul Globe (December 4, 1900), p. 1. Available at: http://chroniclingamerica.loc.gov/lccn/sn90059523/1900-12-04/ed-1/seq-1/ (accessed 30 May 2015).

n.a., The Times, Richmond VA (December 4, 1900), p. 1. Available at: http://chroniclingamerica.loc.gov/lccn/sn85034438/1900-12-04/ed-1/seq-1/ (accessed 30 May 2015).

Allen CJ and Hamilton JM (2010) Normalcy and Foreign News. Journalism Studies 11(5): 634-649.

Aubrey J (2000) Brief Lives. Buchanan-Brown J (ed.), London; New York: Penguin.

Bennett WL, Lawrence RG and Livingston S (2007) When the Press Fails: Political Power and the News Media from Iraq to Katrina. Chicago, Ill.: University of Chicago Press.

Chalaby J (1996) Journalism as an Anglo-American Invention: A Comparison of the Development of French and Anglo-American Journalism, 1830s-1920s. European Journal of Communication 11: 303-326.

Cook, T (2005) Governing with the News: The News Media as a Political Institution. Chicago: University of Chicago Press.

Cordell R (2015) Reprinting, Circulation, and the Network Author in Antebellum Newspapers. American Literary History 27(3): 417-445.

Darnton R (2000) An Early Information Society: News and the Media in Eighteenth-Century Paris. American Historical Review 105(1): 1-35.

Darnton R (2013) Blogging, Now and Then (250 Years Ago). European Romantic Review 24(3): 255270.

Dias BG and Ressler KJ (2014) Parental Olfactory Experience Influences Behavior and Neural Structure in Subsequent Generations. Nature Neuroscience 17(1): 89-96.

Fraser A (1979) King Charles II. London: Weidenfeld \& Nicolson.

Fukuyama F (1992) The End of History and the Last Man. New York: Free Press.

Fulda B (2009) Press and Politics in the Weimar Republic. Oxford: Oxford University Press. 
Hall A (1977) Scandal, Sensation, and Social Democracy: The SPD Press and Wilhelmine Germany 1890-1914. Cambridge: Cambridge University Press.

Hallin DC (1986) The 'Uncensored War': The Media and Vietnam. New York: Oxford University Press.

Hamilton J (2004) All the News That's Fit to Sell: How the Market Transforms Information into News. Princeton, NJ: Princeton University Press.

Hamilton JM (2009) Journalism's Roving Eye: A History of American Foreign Reporting. Baton Rouge: Louisiana State University Press.

Hamilton JM and Krimsky GA (1996) Hold the Press: The Inside Story on Newspapers. Baton Rouge: Louisiana State University Press.

Hazlitt W (1835) The Character of W. Cobbett M.P. in Table-Talk: Essays on Men and Manners, vol I, essay 6. Available at: http://www.gutenberg.org/files/3020/3020-h/3020-h.htm\#link2H_4_0007 (accessed 15 April 2015).

Hertle H-H and Saure H-W (2015) Ausgelacht. DDR-Witze aus den Geheimakten des BND. Berlin: Christoph Links Verlag.

Hudson F (1873) Journalism in the United States, from 1690-1872. New York: Harper \& Brothers.

John RR (1995) Spreading the News: The American Postal System from Franklin to Morse. Cambridge, Mass.: Harvard University Press.

John RR and Silberstein-Loeb J (eds) (2015) Making News: The Political Economy of Journalism in Britain and America from the Glorious Revolution to the Internet. Oxford: Oxford University Press.

Johnson C (2015) In Science, Irreproducible Research is a Quiet Crisis. Boston Globe, Available at: www.bostonglobe.com/ideas/2015/03/19/science-irreproducible-research-quietcrisis/xunxnfuzwdwYSpVjkx2iQN/story.html (accessed 19 August 2015).

Keefe PR (2013) Rocket Man: How an Unemployed Blogger Confirmed that Syria had Used Nuclear Weapons. The New Yorker. Available at: http://www.newyorker.com/magazine/2013/11/25/rocket-man-2 (accessed 19 August 2015).

Kellermann NP (2013) Epigenetic Transmission of Holocaust Trauma: Can Nightmares be Inherited? The Israel Journal of Psychiatry and Related Sciences 50(1): 33-39.

Kenez P (1985) The Birth of the Propaganda State: Soviet Methods of Mass Mobilization, 1917-1929. Cambridge, UK: Cambridge University Press.

Knowlton SR and Freeman KL (eds) (2005) Fair \& Balanced: A History of Journalistic Objectivity. Northport, AL: Vision Press. 
Koestler A (1983) Arrow in the Blue: The First Volume of an Autobiography, 1905-31. London: Hutchinson.

Lippmann W (1931) Two Revolutions in the American Press. Yale Review 20(3): 433-441.

Lippmann W and Merz C (1920) A Test of the News: An Examination of the News Reports in the New York Times on Aspects of the Russian Revolution of Special Importance to Americans, March 1917-March 1920. New Republic. Available at: https://archive.org/details/LippmannMerzATestoftheNews (accessed 19 August 2015).

Lochner L (1931) Hinter den Kulissen der amerikanischen Berichterstattung. Deutsche Presse. Sonderdruck Nr. 7/8: 2-5.

Malatesta M (2011) Professional Men, Professional Women: The European Professions from the Nineteenth Century until Today. London: SAGE.

Maras S and Nip JYM (2015) The Travelling Objectivity Norm. Journalism Studies 16(3): 326-342.

Mindich DTZ (1998) Just the Facts: How 'Objectivity’ Came to Define American Journalism. New York: New York University Press.

Moss SP (1984) Charles Dickens' Quarrel with America. Troy, NY: Whitston Publishing Co.

Nalbach A (2003) 'Poisoned at the Source'? Telegraphic News Services and Big Business in the Nineteenth Century. Business History Review 77(4): 577-610.

Nerone J (2013) The Historical Roots of the Normative Model of Journalism. Journalism 14(4): 446458.

Picard RG (2008) News Consumption and the Business of Journalism. In New Models for News. Baton Rouge: Manship School of Mass Communications. Available at: http://uiswcmsweb.prod.lsu.edu/manship/ReillyCenter/PublicationsandResources/papers/item25 318.pdf (accessed 19 August 2015), pp. 112-119.

Nicholson B (2012) 'You Kick the Bucket; We Do the Rest!': Jokes and the Culture of Reprinting in the Transatlantic Press. Journal of Victorian Culture 17(3): 273-286.

Pagett JF and Powell WW (2012) The Emergence of Organizations and Markets. Princeton, NJ: Princeton University Press.

Park RE (1923) The Natural History of the Newspaper. American Journal of Sociology 29(3): 273-289.

Pettegree A (2014) The Invention of News: How the World Came to Know about Itself. New Haven: Yale University Press.

Picard RG (2003) Cash Cows or Entrecôte: Publishing Companies and Disruptive Technologies. Trends in Communication 11(2): 127-136.

Rantanen T (2007) The Cosmopolitanization of News. Journalism Studies 8(6): 843-861. 
Sassen S (2001) The Global City: New York, London, Tokyo. 2nd ed. Princeton, NJ: Princeton University Press.

Schröder WH (2009) Kollektive Biographik: Forschungsstratgie des BIOSOP-Projektes. Available at: http://biosop.zhsf.uni-koeln.de/texte/biosop_projekt.html (accessed 20 February 2012).

Schudson M (1990) Origins of the Ideal of Objectivity in the Professions: Studies in the History of American Journalism and American Law, 1830-1940. New York: Garland Pub.

Schudson M (1995) The Power of News. Cambridge, Mass.: Harvard University Press.

Schudson M (2001) The Objectivity Norm in American Journalism. Journalism 2(2): 149-170.

Sebastian M (2015) Native Ads were 'Inside' 10\% of Digital at The New York Times Last Year. Ad Age. Available at: http://adage.com/article/media/york-times-sold-18-2-million-worth-nativeads/296966/ (accessed 1 June 2015).

Silberstein-Loeb J (2014) The International Distribution of News: The Associated Press, Press Association, and Reuters, 1848-1947. Cambridge, UK: Cambridge University Press.

Slatkin M (2009) Epigenetic Inheritance and the Missing Heritability Problem. Genetics 182(3): 845850.

Splichal S (2002) Principles of Publicity and Press Freedom. Rowman \& Littlefield.

Stannard Baker R (2012) A Journalist's Diplomatic Mission: Ray Stannard Baker's World War I Diary. Hamilton JM and Mann R (eds), Baton Rouge: Louisiana State University Press.

Starr P (2004) The Creation of the Media. Political Origins of Modern Communications. New York: Basic Books.

Stead WT (1891) How to Become a Journalist: Some Practical Advice for Beginners. The Review of Reviews, vol. 3. Available at: http://www.attackingthedevil.co.uk/reviews/howjourn.php (accessed 15 April 2015).

Steel J and Broersma M (2015) Redefining Journalism During the Period of the Mass Press 1880-1920. Media History 21(3): 235-237.

Swing R (1964) “Good Evening!” A Professional Memoir. New York: Harcourt, Brace and World.

Tworek HJS (2013) The Creation of European News: News Agency Cooperation in Interwar Europe. Journalism Studies 14(5): 730-742.

Vos TP (2012) 'Homo journalisticus': Journalism Education's Role in Articulating the Objectivity Norm. Journalism 13(4): 435-449.

Winder GM and Schmitt M (2014) Geographical Imaginaries in The New York Times' Reports of the Assassinations of Mahatma Gandhi (1948) and Indira Gandhi (1984). Journal of Historical Geography 45: 106-115. 
Zhao Y (2012) Understanding China's Media System in a World Historical Context. In Hallin DC and Mancini P (eds) (2012) Comparing Media Systems beyond the Western World. New York:

Cambridge University Press, pp. 143-176. 